\title{
ANALISIS VARIASI HARGA BERAS DI PROVINSI RIAU DAN DAERAH PEMASOK
}

\section{Analysis of Rice Price Variation in Riau Province and Supplier Areas}

\author{
Desmayanti Jusar ${ }^{1}$, Djaimi Bakce ${ }^{2}$ dan Eliza ${ }^{2}$ \\ ${ }^{1}$ Mahasiswa Pasca Sarjana Fakultas Pertanian Universitas Riau \\ ${ }^{2}$ Dosen Jurusan Agribisnis Fakultas Pertanian Universitas Riau \\ [Diterima: Juli 2017; Disetujui: Agustus 2017]
}

\begin{abstract}
Riau is one of the provinces that is highly dependent on the supplier area, not the producer area, but the rice consumer net. This causes the price of rice to fluctuate, so the observation of rice price development is very important for the Government of Riau Province. Price fluctuations with large variations are a problem whereas price fluctuations with low variations are relatively controllable, so research on the analysis of price variations, important to do. The results show that overall rice price variation in Riau Province and supplier areas in 2006 - 2015 were is relatively stable with an increasing trend but there was a rice price jump in 2008 as a result of the global economic crisis, where food prices are rising while revenues decrease.
\end{abstract}

Keywords: Rice, Price Fluctuation, Price Variation, Variation coefficient

\begin{abstract}
ABSTRAK
Riau merupakan salah satu provinsi yang sangat tergantung kepada daerah pemasok, bukan daerah produsen, namun net konsumen beras. Hal ini mengakibatkan harga beras cenderung berfluktuasi sehingga pengamatan tentang perkembangan harga beras sangat penting bagi Pemerintah Provinsi Riau. Fluktuasi harga dengan variasi yang besar merupakan suatu permasalahan sedangkan fluktuasi harga dengan variasi yang rendah merupakan suatu yang relatif terkendali, sehingga penelitian dengan analisis variasi harga penting dilakukan. Hasil penelitian menunjukkan bahwa secara keseluruhan variasi harga relatif stabil dengan kecenderungan meningkat, namun terjadi lompatan harga beras pada tahun 2008 akibat dari krisis ekonomi global, di mana harga pangan meningkat sementara pendapatan menurun.
\end{abstract}

Kata Kunci: Fluktuasi Harga, Variasi Harga, Koefisien Harga

\section{PENDAHULUAN}

Harga memainkan peran penting dalam ekonomi pasar. Harga merupakan salah satu faktor yang menentukan setiap keputusan produsen dan konsumen dalam mengalokasikan sumber daya yang terbatas agar menuju pada kondisi Pareto optimal atau kondisi keseimbangan (Brummer et al., 2009). Menurut Nicholson (2004), harga pasar memiliki dua fungsi utama, yakni: (i) sebagai informasi mengenai jumlah komoditas yang sebaiknya ditawarkan oleh produsen untuk memperoleh keuntungan maksimum; dan (ii) sebagai faktor penentu tingkat permintaan bagi konsumen yang menginginkan kepuasan maksimum.
Harga yang terbentuk untuk suatu komoditas merupakan hasil interaksi antara penawaran (penjual) dan permintaan (pembeli). Semakin banyak barang yang ingin dibeli akan meningkatkan harga, sementara semakin banyak barang yang akan dijual akan menurunkan harga. Banyak faktor yang dapat mempengaruhi perilaku permintaan maupun penawaran dalam interaksi pembentukan harga. Namun, untuk komoditas pangan atau pertanian, pembentukan harga disinyalir lebih dipengaruhi oleh sisi penawaran (supply shock) dibandingkan sisi permintaan (demand shock). Sisi penawaran lebih berpengaruh karena sisi permintaan cenderung lebih stabil dibanding sisi penawaran yaitu mengikuti perkembangan trendnya. 
Perubahan penawaran pangan dengan nilai elastisitas penawaran dan permintaan yang inelastis akan menyebabkan besarnya fluktuasi harga (Nicholson, 2002).

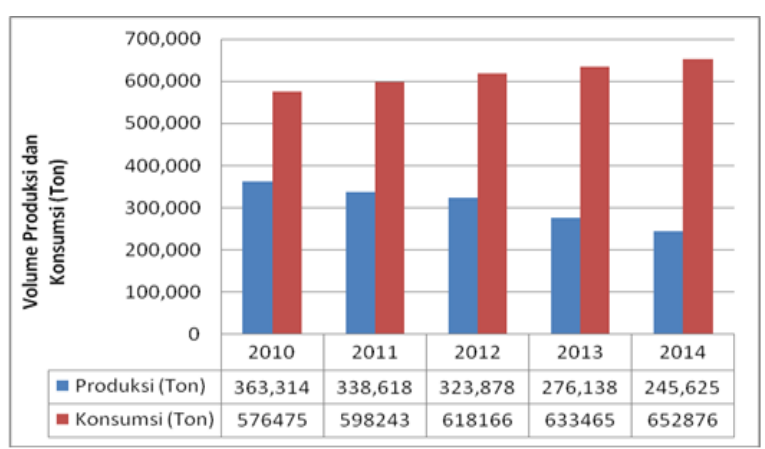

Sumber: BKP Provinsi Riau (2015)

Gambar 1. Perkembangan Produksi dan Konsumsi Beras Riau Tahun 20102014.

Harga komoditas pangan mempunyai peranan penting dalam pengendalian inflasi. Kenaikan harga bahan pangan juga digolongkan oleh Badan Pusat Statistik (BPS) sebagai komponen inflasi bergejolak (volatile foods), karena sifatnya yang mudah dipengaruhi oleh masa panen, gangguan alam, harga komoditas bahan pangan domestik dan internasional. Porsi sumbangannya yang cukup signifikan terhadap inflasi dan responnya yang cepat terhadap berbagai shocks membuatnya layak untuk dijadikan leading indicators inflasi (Prastowo et al. 2008)

Harga beras sebagai pangan pokok utama masyarakat Riau berfluktuasi dengan kecendrungan meningkat. Faktor penyebabnya adalah kebutuhan yang cenderung meningkat, sedangkan produksi lokal yang cendrung menurun, sehingga perlu memasok beras dari provinsi lain bahkan dari negara lain. Perkembangan produksi dan konsumsi beras di Provinsi Riau dapat dilihat pada Gambar 1.

Dengan kondisi Provinsi Riau sebagai net importir tersebut, menyebabkan harga beras di Provinsi Riau berfluktuasi. Menurut Murty (2000) faktor-faktor ekonomi yang menyebabkan terjadinya variasi harga antar wilayah adalah adanya kekuatan pasar, distorsi pasar dan kebijakan harga. Fluktuasi harga dengan variasi yang besar merupakan suatu permasalahan sedangkan fluktuasi harga dengan variasi yang rendah merupakan suatu yang relatif terkendali. Pemerintah maupun masyarakat berkepentingan terhadap harga komoditas pangan yang (relatif) stabil. Stabilisasi harga pangan perlu dilakukan agar pembangunan ekonomi berjalan lancar dan kondusif untuk mendukung terciptanya stabilitas politik, dan keamanan.

Setidaknya terdapat dua alasan mengapa analisis harga beras penting untuk dilakukan, dalam hal ini terkait dengan tujuan melakukan analisis harga yaitu (1) untuk mengestimasi koefisien (parameter) ekonomi tertentu seperti elastisitas permintaan dari harga beras, dan (2) untuk meramalkan (forecasting) harga pada masa datang dan faktor-faktor yang mempengaruhi tingkat harga beras.

Salah satu analisis harga adalah Variasi Harga dengan menggunakan prinsip Koefisien Variasi. Penelitian ini bertujuan untuk menganalisis variasi harga beras di Provinsi Riau dan Daerah Pemasok.

\section{METODE PENELITIAN}

Penelitian ini membahas tentang variasi harga beras, dengan asumsi disamping dipengaruhi oleh produksi lokal juga dipengaruhi oleh jumlah pasokan dari daerah lain. Oleh karenanya, data yang dikumpulkan adalah data eceran beras di Provinsi Riau dan dari daerah pemasok meliputi Provinsi Sumatera Utara, Provinsi Sumatera Barat, Provinsi Sumatera Selatan, Provinsi Lampung, Provinsi Jawa Timur dan Negara Thailand.

Data yang dikumpulkan adalah data time series bulanan mulai dari Bulan Januari 2006 sampai Desember 2015 atau 120 bulan. Datadata tersebut dikumpulkan dari sumber meliputi: Kementerian Perdagangan RI, Worldbank, Badan Pusat Statistik Indonesia, Bank Indonesia, Badan Ketahanan Pangan Riau dan Kementerian Pertanian RI.

Variasi harga beras menggunakan data harga eceran beras kualitas medium Provinsi Riau dan Daerah Pemasok. Alasan memilih daerah/negara tersebut adalah dengan mempertimbangkan merupakan daerah produksi padi yang berlebih/surplus dan tingkat perdagangan beras yang tinggi ke Provinsi Riau, serta Thailand merupakan negara pengekspor beras terbesar ke Indonesia. Data harga beras Thailand dikonversi kedalam nilai rupiah dengan memperhitungkan nilai tukar rupiah (Rp) terhadap Dollar Amerika (USD). 
Menganalisis variasi harga beras dilakukan dengan menggunakan koefisien variasi. Koefisien Variasi (CV) merupakan rasio antara simpangan standar (standard deviation) dengan nilai rata-rata, yang dinyatakan dalam persentase, yang berguna untuk melihat sebaran data dari rata-rata hitungnya (Walpole, 2000). Secara matematis dirumuskan dengan:

dimana:

\section{$\overline{\overline{\mathrm{x}}}$}

$\mathrm{C}_{\mathrm{v}}=$ koefisien variasi

$\sigma \quad=$ simpangan baku

$=\quad$ rata-rata variable

Koefisien variasi dari data harga secara runtun waktu menggambarkan fluktuasi yang digunakan untuk mengetahui stabilitas harga suatu komoditas. Semakin kecil koefisien variasi harga komoditas dapat mengindikasikan stabilitas harga komoditas yang terkendali, atau dengan kata lain rata-rata harga komoditas tersebut tidak mengalami fluktuasi harga yang ekstrim. Harga di suatu kota/provinsi dikatakan stabil apabila nilai koefisien variasi harganya berada pada kisaran $<9 \%$, sesuai dengan target Kementerian Perdagangan RI sampai dengan tahun 2019 (Kemendag RI, 2015). Jika nilai koefisien variasi lebih dari $9 \%$ mengindikasikan harga berfluktuasi tinggi dan tidak stabil.

\section{HASIL DAN PEMBAHASAN}

Harga pada umumnya ditentukan oleh adanya hubungan yang terjadi antara permintaan dan penawaran. Dalam kenyataannya harga sering berfluktuasi, hal ini disebabkan oleh tiga alasan, yaitu karena naik turunnya permintaan (fluctuation in demand), naik turunnya penawaran (fluctuation in supply) dan eksperimentasi dalam proses penentuan harga.

Sasaran pengembangan distribusi suatu komoditas mencakup tercapainya stabilitas harga antar waktu dan antar wilayah, sehingga seluruh rumah tangga dapat menjangkau kebutuhannya dalam jumlah dan kualitas yang cukup sepanjang waktu. Harga suatu produk pada dasarnya merupakan rangkuman dari sejumlah informasi yang menyangkut ketersediaan sumberdaya, kemungkinan produksi dan preferensi konsumen. Informasi harga merupakan salah satu komponen penting dalam informasi pasar, yang sangat diperlukan terutama oleh petani dan produsen.

Harga beras terus mengalami perubahan dari waktu kewaktu, dan cenderung meningkat setiap tahunnya. Stabilisasi harga beras menjadi salah satu sasaran pembangunan ekonomi nasional karena kenaikan harga beras akan berdampak terhadap daya beli rumah tangga berpendapatan rendah dan meningkatkan inflasi. Peningkatan harga beras juga secara psikologis dapat mempengaruhi perilaku pedagang untuk meningkatkan harga pangan lainnya.

Perkembangan harga eceran beras di Provinsi Riau dan daerah pemasok periode Bulan Januari 2006-Desember 2015 memiliki kecenderungan atau trend yang sama yaitu mengalami peningkatan setiap bulannya, dengan kenaikan drastis taerjadi pada Bulan Juni 2008. Namun terlihat pada bulan-bulan tertentu terjadi dimana fluktuasi harga eceran beras di Provinsi Riau dan daerah pemasok bergerak berlawanan arah yaitu harga eceran beras di Provinsi Riau mengalami peningkatan sedangkan di daerah pemasok mengalami penurunan (Gambar 2).

Hasil penelitian Resnia (2012) juga menunjukkan bahwa harga komoditas pangan cenderung meningkat sebesar $5-12$ persen per tahun selama periode 1999-2011. Penelitian yang dilakukan Trostle (2008) menyebutkan bahwa harga pangan dunia seperti biji-bijian dan minyak sayuran mengalami peningkatan harga yang sangat tajam hingga 60 persen hampir di seluruh belahan dunia selama tahun 2007-2008. Selanjutnya, penelitian yang dilakukan oleh Resnia (2012) menyatakan bahwa pada periode 1999-2011 beras mengalami fluktuasi harga dengan nilai koefisien variasi sebesar 13.7 persen.

Berdasarkan hasil rata-rata nilai koefisien variasi harga beras tahun 2006-2015 (Gambar 3), dapat dilihat bahwa fluktuasi harga beras di Provinsi Riau dan daerah pemasok (Sumatera Barat, Sumatera Utara, Sumatera Selatan, Lampung dan Jawa Timur) relatif rendah dan stabil berdasarkan kriteria Kemendag, karena berada di bawah 9\%. Kecuali di Negara Thailand, fluktuasi harga beras relatif tinggi dan tidak stabil, ditunjukkan dengan nilai rata-rata Koefisen Variasi sebesar 9,46\%. 


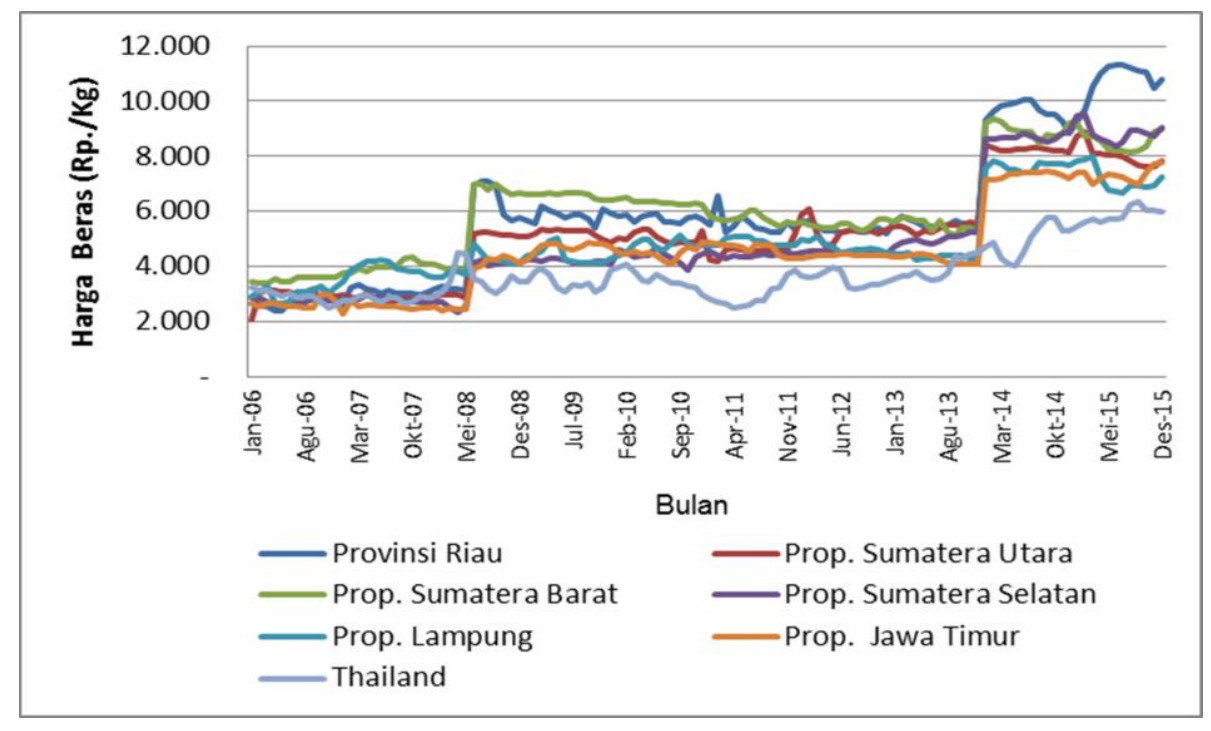

Sumber: Kemendag RI (2016), data diolah

Gambar 2. Perkembangan Harga Eceran Beras di Provinsi Riau dan Daerah Pemasok Bulan Januari 2006-Desember 2015

Fluktuasi harga beras di Provinsi Riau dan seluruh daerah pemasok pada tahun 2008, memperlihatkan fluktuasi yang tinggi dan tidak stabil, diperlihatkan dengan nilai rata-rata Koefisien Variasi yang tinggi yaitu 23,05\%. Hal ini disebabkan karena Krisis pangan dunia yang terjadi pada tahun 2007-2008 mengakibatkan peningkatan harga pangan di pasar dunia. Peningkatan harga pangan dunia tersebut berimbas pada peningkatan harga pangan di pasar domestik Indonesia, termasuk harga beras di Provinsi Riau.
Menurut Magdoff (2008), kenaikan harga pangan disebabkan oleh (1) Kenaikan harga minyak dunia; (2) Meningkatnya permintaan daging di antara kelas menengah di Amerika Latin, Asia, dan khususnya Cina; (3) ketika beberapa negara dengan jumlah penduduk besar seperti India dan Cina, justru menjadi importir pangan terbesar; dan (4) Perubahan iklim secara tiba-tiba, seperti bencana alam.

Kenaikan harga yang drastis kembali terjadi pada Bulan Januari 2014 dibandingkan bulan sebelumnya, hal ini disebabkan karena

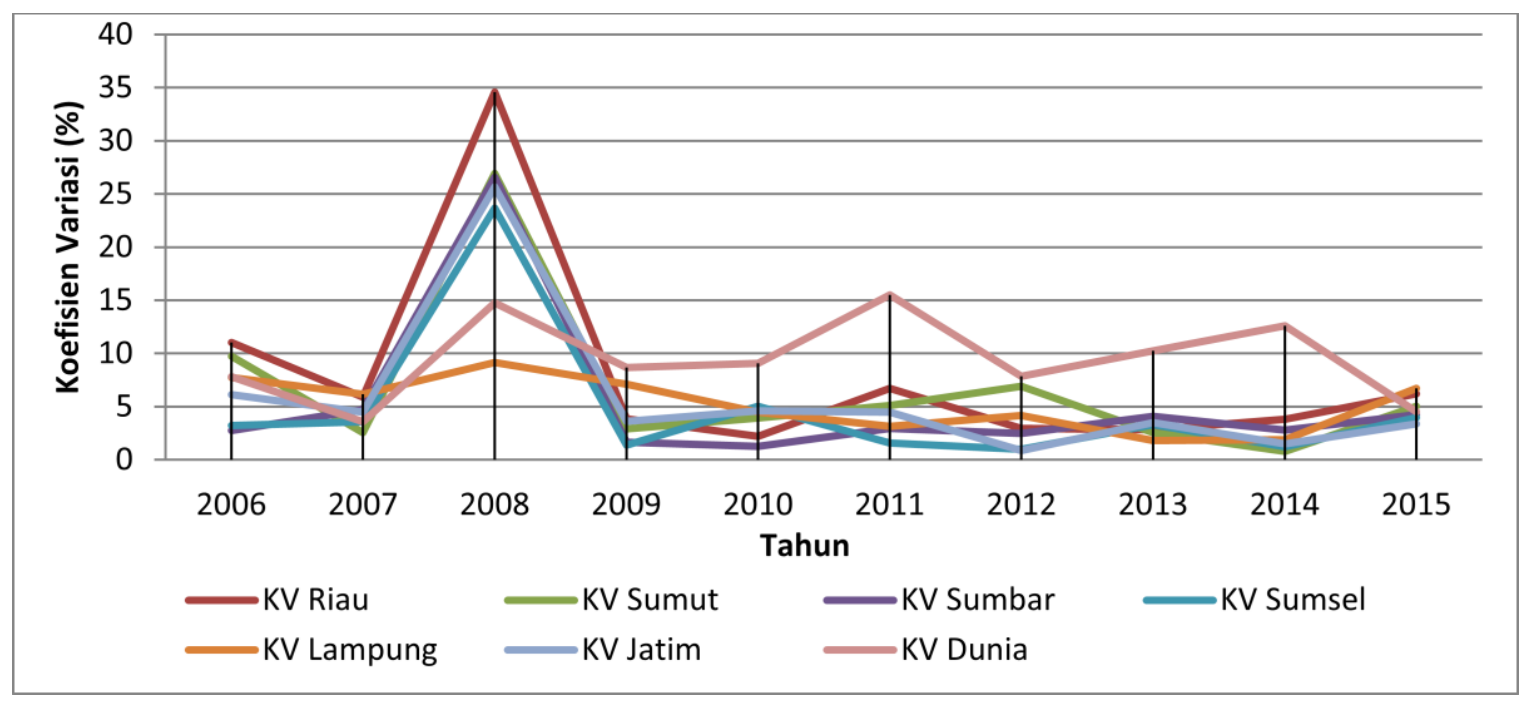

Sumber: Kemendag RI (2016), data diolah

Gambar 3. Koefisien Variasi (KV) Harga Beras Provinsi Riau dan Daerah Pemasok Tahun 20062015 
terjadi kelangkaan beras hampir di seluruh wilayah Indonesia. Pasokan beras lokal tidak mampu memenuhi kebutuhan beras dalam negeri, sementara pemerintah membatasi volume impor beras sehubungan dengan program swasembada beras. Ketidakseimbangan permintaan dan penawaran ini, dimana permintaan lebih tinggi dari penawaran menyebabkan harga menjadi naik.

Fluktuasi harga sebenarnya merupakan suatu hal yang normal dan diperlukan agar fungsi pasar tetap berjalan, yaitu tercipta pasar yang kompetitif. Perubahan dari harga akan menjadi masalah apabila harga melonjak sangat tinggi dan tidak dapat diprediksi yang nantinya akan menciptakan suatu ketidakpastian yang mampu meningkatkan risiko bagi produsen, pedagang, konsumen, dan tentu juga pemerintah. Perubahan dari harga yang tidak merefleksikan kinerja pasar akan menciptakan permasalahan baru, yaitu dapat menciptakan kesalahan kebijakan yang akan diambil pemerintah (Kemendag RI, 2015).

Analisis variasi harga digunakan untuk mengetahui stabilitas harga beras di Provinsi Riau dan Daerah Pemasok. Semakin kecil nilai koefisien variasinya dapat diinterpretasikan bahwa harga relatif stabil atau mempunyai tingkat fluktuasi yang rendah. Stabilitas harga merupakan salah satu indikator yang dapat digunakan untuk memberikan sinyal kepada produsen terhadap faktor risiko harga yang mungkin akan dihadapi seorang produsen dan kepada pemerintah dalam rangka perlindungan terhadap produsen dan konsumen.

Harga beras Provinsi Riau menunjukkan laju pertumbuhan dan fluktuasi lebih tinggi dibandingkan dengan harga daerah pemasok (Sumatera Barat, Sumatera Utara, Sumatera Selatan, Lampung dan Jawa Timur) namun relatif lebih stabil dibanding harga beras Thailand. Hal ini disebabkan karena sebagai net importir, Provinsi Riau sangat tergantung dengan pasokan dari daerah lain, sehingga harga beras lebih berfluktuatif.

Beras merupakan komoditi sensitif yang selalu diintervensi oleh pemerintah dalam rangka menjaga stabilitas harga pangan pokok. Dari nilai rata-rata koefisien variasi harga beras Riau yang lebih tinggi dibandingkan dengan daerah pemasok menunjukkan bahwa Pemerintah Provinsi Riau belum mampu menjaga kestabilan harga beras dengan baik, dikarenakan posisi Riau sebagai "net importir" beras dari daerah pemasok.

Berdasarkan hasil survei Badan Pusat Statistik (BPS Indonesia, 2015) diketahui bahwa asal pasokan beras di Provinsi Riau tidak hanya berasal dari dalam Riau. Pasokan beras dari dalam Provinsi Riau justru hanya sebesar 7,96 persen, sementara sebagian besar lainnya berasal dari beberapa provinsi sekitar, seperti: Sumatera Utara, Sumatera Barat, Sumatera Selatan, dan Lampung. Provinsi pemasok beras terbesar untuk wilayah Riau berasal dari Sumatera Barat dan Sumatera Selatan, masingmasing 46,43 persen dan 34,04 persen.

Upaya yang dilakukan oleh Pemerintah Provinsi Riau dalam rangka meningkatkan produksi padi antara lain yaitu melalui Program Operasi Pangan Riau Makmur pada tahun 20092013 dan mendukung Program Upsus PaJaLe (2015-2017). Upaya peningkatan produksi padi/beras di Provinsi Riau sampai saat ini belum mampu menjadikan Riau swasembada beras tetapi untuk mengurangi tingkat ketergantungan pengadaan dari luar. Untuk memenuhi defisit tersebut, suplai beras dilakukan oleh lembaga pemerintah (Bulog) dan non pemerintah (pedagang) melalui penetapan HPP, menyerap gabah dan beras petani serta Operasi Pasar.

Hasil survei Badan Pusat Statistik (BPS Indonesia, 2015), 99,22 persen pasokan beras yang diperoleh pedagang di Provinsi Sumatera Barat berasal dari dalam Sumatera Barat. Sementara sebagian kecil sisanya didapat para pedagang dari Sumatera Utara maupun Jambi. Pasokan beras tersebut kemudian dijual ke dalam Provinsi Sumatera Barat sendiri sebesar 84,51 persen dan sisanya dijual ke beberapa provinsi sekitar seperti Riau, Jambi, dan Sumatera Selatan.

Produksi padi di Provinsi Sumatera Barat relatif stabil setiap tahunnya dikarenakan sistem pertanianannya yang bersifat turun temurun (Tanah Tinggi), sehingga luas lahan pertanian relatif tetap. Selain itu, kebiasaan di Sumatera Barat bahwa petani melakukan penanaman padi tidak serentak, dengan terjaminnya ketersediaan beras sepanjang tahun, menyebabkan harga beras di Sumatera Barat relatif stabil.

Berdasarkan hasil survei (BPS Indonesia, 2015), ditemukan bahwa selain mendapat pasokan beras dari dalam Provinsi Sumatera Utara sendiri sebesar 95,94 persen, pasokan 
beras di Provinsi Sumatera Utara juga berasal dari Provinsi Aceh. Bahkan menurut informasi petani di Kabupaten Siak dan Rokan Hilir, bahwa gabah yang berasal dari kabupaten tersebut dibeli oleh pedagang dari Sumatera Utara. Pasokan beras tersebut kemudian seluruhnya dijual ke dalam Provinsi Sumatera Utara sendiri dan sisanya dijual ke Riau.

Pemerintah Provinsi Sumatera Utara mengeluarkan kebijakan kebijakan dalam rangka peningkatan produksi padi. Sebagai daerah surplus beras, ketersediaan beras di Provinsi Sumatera Utara terjamin sepanjang tahun, sehingga harga beras relatif stabil.

Pasokan beras di Provinsi Sumatera Selatan sebagian besar berasal dari Sumatera Selatan dan sebagian kecil dari Provinsi Lampung. Pasokan beras tersebut oleh pedagang kemudian dijual ke dalam Provinsi Sumatera Selatan sebesar 95,35 persen, sedangkan sisanya dijual ke Jambi, Lampung, dan DKI Jakarta.

Pemerintah Provinsi Sumatera Selatan mengeluarkan kebijakan kebijakan dalam rangka peningkatan produksi padi. Sebagai daerah surplus beras, ketersediaan beras di Provinsi Sumatera Selatan terjamin sepanjang tahun, sehingga harga beras relatif stabil.

Pasokan beras di Provinsi Lampung seluruhnya berasal dari dalam Provinsi Lampung sendiri. Seluruh pasokan beras tersebut juga hanya digunakan untuk memenuhi kebutuhan beras di wilayah Lampung sendiri. Beras hasil produksi dari penggilingan beras yang ada di provinsi Lampung sebagian besar dijual melalui pemerintah dan lembaga nirlaba serta pedagang pengepul. Hanya sebagian kecil saja dari produksi beras tersebut yang dijual melalui agen, pedagang grosir, supermarket/ swalayan, pedagang eceran, mapun langsung ke konsumen akhir, sehingga harga beras relatif stabil karena bisa diintervensi dengan baik oleh pemerintah (BPS Indonesia, 2015). Kebijakan yang dilakukan oleh Pemerintah Provinsi Lampung tersebut menyebabkan harga beras di Provinsi Lampung relatif stabil.

Distribusi perdagangan komoditas beras di Provinsi Jawa Timur menunjukkan bahwa pasokan beras yang masuk ke dalam wilayah Provinsi Jawa Timur sebagian besar berasal dari dalam wilayah sendiri, yaitu sebesar 98,30 persen. Pasokan beras lainnya berasal dari Jawa Tengah sebesar 0,76 persen dan sisanya sebesar
0,94 persen berasal dari Jawa Barat. Pasokan beras tersebut kemudian seluruhnya dipergunakan untuk memenuhi kebutuhan akan beras di dalam Provinsi Jawa Timur sendiri dan sisanya dijual keluar Provinsi Jawa Timur (BPS Indonesia, 2015).

Jawa Timur sebagai salah satu daerah sentra produksi beras di Indonesia, pemerintahnya berupaya keras untuk menjaga ketersediaan beras dan kestabilan harga beras yaitu dengan cara menciptakan manajemen pertanian berbasis kearifan lokal dan potensi lokal, membanngun infrastruktur pertanian, serta membentuk Bank Petani. Hasil penelitian Irawan (2005) menunjukkan bahwa kebijakan laju konversi lahan sawah di Jawa, Bali dan NTB ditekan sampai 0\% mulai tahun 2010 (penetapan lahan sawah abadi) dan peningkatan produktivitas padi sebesar 2,5\%/tahun.

Dari Gambar 3 terlihat bahwa fluktuasi harga beras di Negara Thailand sangat berfluktuatif dan relatif tidak stabil, dimana nilai koefisien variasi terendah 3,58 - yang tertinggi 15,49. Di pasar dunia, beras memiliki skala pasar yang sempit (thin market). Artinya, hanya sedikit volume beras yang diperdagangkan oleh setiap negara produsen beras di pasar dunia. Hal ini terjadi karena pada hakikatnya, komoditi beras merupakan komoditi pokok di negara-negara pengekspor, sehingga tujuan utama setiap negara adalah untuk memenuhi kebutuhan negaranya terlebih dahulu baru kemudian sisanya di ekspor. Kondisi "thin market" ini menyebabkan jika terjadi sedikit saja shock di pasar dunia, contohnya shock dari kenaikan harga minyak mentah dunia maka akan mempengaruhi harga beras dunia, sehingga menjadikan ketersediaan beras dan harga yang terjadi sangat fluktuatif. (Chintia, S., 2013).

Beras merupakan komoditas yang dapat disimpan/stok sehingga jumlah stok juga berpengaruh terhadap harga beras di pasar. Jumlah pasokan juga merupakan faktor yang penting dalam stabilitas harga, kelancaran pasokan akan membuat para pedagang di pasar dapat memenuhi kebutuhan konsumen dengan cepat.

Hasil kajian dari Bank Indonesia Bandung bekerjasama dengan Fakultas Ekonomi Universitas Padjadjaran (2012), merekomendasikan kebijakan pengendalian harga beras memerlukan peran pemerintah 
provinsi dan kabupaten/kota berkoordinasi dengan Bulog divisi regional. Hal ini berdasarkan situasi adanya variasi dan fluktuasi harga beras antar daerah, baik antar kabupaten/kota maupun kecamatan yang berpotensi mendorong inflasi beras. Kebijakan terutama terkait dengan monitoring dan pengendalian stok beras secara berkala (bulanan) serta operasi pasar. Kegiatan monitoring perlu dilakukan lebih intensif terhadap pergerakan harga beras di beberapa daerah yang dinilai mempunyai efek kuat terhadap pembentukan harga beras.

Deviasi dan fluktuasi harga beras akan terjadi pada saat arus beras keluar dan masuk daerah kurang stabil, maka diperlukan pula kebijakan pemerintah daerah untuk secara berkala menyeimbangkan produksi, stok dan kebutuhan di dalam suatu wilayah melalui peran aktif Dinas perdagangan, Dinas Pertanian Tanaman Pangan dan Bulog.

\section{KESIMPULAN DAN SARAN}

\section{a. Kesimpulan}

Berdasarkan hasil penelitian yang telah dilakukan, maka dapat ditarik kesimpulan sebagai berikut:

1. Harga eceran beras di Provinsi Riau dan di daerah pemasok berfluktuasi setiap bulan dan cenderung naik. Kenaikan harga tertinggi terjadi pada tahun 2008 yang disebabkan karena krisis pangan dunia.

2. Dari hasil analisis variasi harga diketahui bahwa nilai rata-rata koefisien variasi harga beras dari tahun 2006-2015 di Provinsi Riau dan Daerah Pemasok (Sumatera Utara, Sumatera Barat, Sumatera Selatan, Lampung, Jawa dan Timur) relatif stabil karena berada di bawah 9\%, berdasarkan pada kriteria Kemendag, kecuali Thailand sebesar 9,46, berada di atas $9 \%$ relatif tidak stabil/berfluktuatif.

3. Dari nilai koefisien variasi Riau yang lebih tinggi dibandingkan dengan daerah pemasok menunjukkan bahwa Pemerintah Provinsi Riau belum mampu menjaga kestabilan harga beras dengan baik, dikarenakan posisi Riau sebagai "net importir" beras dari daerah pemasok.

\section{b. Saran}

Berdasarkan hasil penelitian yang telah dilakukan, maka dapat diberikan saran untuk Mengatasi Fluktuasi Harga sebagai berikut:

1. Untuk mengurangi ketergantungan pasokan beras dari daerah lain yang pada akhirnya dapat mengendalikan harga beras, maka upaya-upaya peningkatan produksi padi harus tetap dilakukan.

2. Pengendalian harga beras memerlukan peran pemerintah provinsi dan kabupaten/kota berkoordinasi dengan Bulog divisi regional. Kebijakan terutama terkait dengan monitoring dan pengendalian stok beras secara berkala (bulanan) serta operasi pasar.

3. Menciptakan manajemen pertanian berbasis kearifan lokal dan potensi lokal, membangun infrastruktur pertanian, serta membentuk Bank Petani.

\section{DAFTAR PUSTAKA}

Bank Indonesia Bandung bekerjasama dengan Fakultas Ekonomi Universitas Padjadjaran. 2012. Pola Pembentukan Harga Beras di Jawa Barat. http://www.bi.go.id/NR/rdonlyres/D8F44 63AEF7F-4ADD-AEE7-FBA518528831/ 10304/Boks1.pdf. Diakses 1 November 2017.

BKP Provinsi Riau. 2015. Data Statistik Ketahanan Pangan Tahun 2014. Badan Ketahanan Pangan Provinsi Riau, Pekanbaru.

BPS Indonesia. Indeks Harga Konsumen 20062015. www.bps.go.id. Diakses 1 November 2016.

BPS Indonesia. 2015. Distribusi Perdagangan Komoditas Beras Indonesia 2015. Badan Pusat Statistik Indonesia, Jakarta.

Brümmer BS, Taubadel VC, Zorya S. 2009. The Impact of Market and Policy Instability on Price Transmission between Wheat and Flour in Ukraine. European Review of Agricultural Economics. 36(2):203230.

Chintia, S. 2013. Dampak Guncangan Harga Minyak Mentah Dunia Terhadap Harga Beras Domestik. Tesis. Sekolah Pasca Sarjana. Institut Pertanian Bogor, Bogor.

Edi, Sirojuzilam dan Rahmanta. 2014. Analisis Integrasi Dan Volatilitas Harga Beras 
Regional Asean Terhadap Pasar Beras Indonesia. Jurnal Ekonomi 17(2): 77-91. Heriyanto, H. (2016). Perilaku Konsumsi Pangan Sumber Karbohidrat Rumahtangga Petani Kelapa Sawit Di Kecamatan Kandis Kabupaten Siak. Jurnal Ilmiah Pertanian, 13(1), 22-30.

Irawan, 2005. Analisis Ketersediaan Beras Nasional: Suatu Kajian Simulasi Pendekatan Sistem Dinamis. Prosiding Seminar Nasional Multifungsi Pertanian dan Ketahanan Pangan. Balittanah, Departemen Pertanian, Bogor.

Khairul, I. 2015. Strategi Pangan Jawa Timur: 447 Ribu Ton Beras untuk 6 Provinsi. www.kompasiana.com/issonkhairul/strate gi-pangan-jawa-timur-447-ribu-tonberas-untuk- 6

provinsi_54f36b387455139f 2b6c74d6. Diakses 21 Juli 2017.

Kemendag RI. 2015. Rencana Strategis Kementerian Perdagangan Periode 20152019. Kementerian Perdagangan RI, Jakarta.

Kemendag RI. 2015. Laporan Akhir Kajian Efektivitas Kebijakan Impor Produk Pangan Dalam Rangka Stabilisasi Harga. Kementerian Perdagangan RI, Jakarta.

Kemendag RI. 2016. Data Harga Beras Provinsi di Indonesia. Kementerian Perdagangan RI,Jakarta.

Kotler dan Keller. 2009. Manajemen Pemasaran. Jilid I. Edisi ke 13. Jakarta: Erlangga.
Kotler, P \& Armstrong. 2010. Principles of Marketing, thirteen edition. New Jersey: Prentice-Hall, Inc.

Magdoff , F. 2008 "The World Food Crisis Sources and Solutions," Monthly Review, Vol 60, No.1, May 2008.

Murty, S. (2000). Regional Disparities: Need and Measures of Balanced Development. In Shukla, AL Ed., Regional Planning and Sustainable Development.

Nicholson, W. 2002. Teori Ekonomi Mikro, Peterjemah Deliarnov. PT. Raja Grafindo Persada, Jakarta.

Nicholson W. 2004. Microeconomic Theory: Basic Principles and Extensions, Ed ke-9. New York (US): Thomson South Western.

Reza, Mohammad. 2015. Analisis Stabilisasi Harga Pangan di Indonesia.Tesis. Sekolah Pasca Sarjana Institut Pertanian Bogor, Bogor.

Walpole. 2000. Pengantar Statistik. Edisi ke-3. Gramedia Pustaka Utama. Jakarta.

World Bank. 2016. Prices (Pink Sheet). www.World Bank.org. Diakses 1 November 2016. 